\title{
Investment Prospect and Risk Analysis of Energy and Power Sector in Greece
}

\author{
Ruan Wenjing ${ }^{1, a}$.Feng Xinxin ${ }^{1, b}$ and Xiao Hanxiong ${ }^{1, c}$ \\ ${ }^{1}$ State Grid Energy Research Institute . Beijing 102209, China
}

\begin{abstract}
Greece's superior location advantages make it a key gateway for global energy enterprises to open the European market. At present, the consolidation of energy security in Greece provides investment opportunities for Chinese energy and power companies. However, it also faces risks such as the strengthening of the EU's foreign investment review.This paper proposes that policy should be further strengthened at the national level, in order to guide domestic energy. At the same time, the enterprises must improve investment strategies and strengthen the construction of transnational operation capacity.
\end{abstract}

\section{Introduction}

Under the "Belt and Road" cooperation framework, China and Greece are pragmatically promoting bilateral economic and trade cooperation and power cooperation. At the government level, in 2018, China and Greece signed a memorandum of understanding on "Belt and Road" cooperation, which provides a broader platform for cooperation between the two countries in the power and energy fields. At the enterprise level, the successful examples of cooperation between Chinese and Greek enterprises in the fields of trade, transportation and energy in recent years have further strengthened the confidence in bilateral cooperation. On December 30, 2020, the leaders of China and the EU jointly announced that the China-EU investment agreement negotiations have been completed as scheduled. The EU-China Investment Agreement is expected to provide a fairer market environment for Chinese companies to invest, and they can use the dispute settlement mechanism to fight for legal rights when they encounter unfair treatment. The policy environment for Chinese companies to expand investment in Europe is expected to improve.

\section{Current Status of Energy and Electricity in Greece}

On the whole, Greece's oil and gas resources are relatively scarce, energy and electricity are highly dependent on each other, energy and electricity reform is imminent, power grid infrastructure lags behind, and it is difficult to achieve the goal of low carbon energy transformation in 2030. Therefore, consolidating energy security, achieving low-carbon development and boosting the country's economy are the most important demands of the Greek government, and also provide more investment opportunities for China's energy and power enterprises.

\subsection{Greece has a high degree of external dependence on energy, and energy reform is imminent.}

From the total energy level, Greece's traditional energy is relatively scarce, high degree of external dependence. The energy structure of Greece is similar to that of China, showing the characteristics of "rich coal, lack of oil and less gas ". In addition to producing a small amount of oil and natural gas in China, oil and gas are highly dependent on imports, and the external dependence of oil and gas is as high as $90 \%$ in 2018. Greece is rich in lignite resources and is the largest coal producer in Europe, but high quality coal is also highly dependent on imports, and the external dependence of coal is about $6.4 \%$. As the European Union restricts the development of coal power, the scale of electricity imports in Greece is also increasing. In order to deal with the domestic debt situation and consolidate energy security, Greece has adopted a series of reform measures, including the privatization of national power assets, the development of new energy to replace fossil energy imports, electricity to replace traditional energy, and so on. These reforms are conducive to the consolidation of Greek energy security and provide an important opportunity for foreign investment to participate in Greek energy cooperation. (Table1)

* Corresponding author: 278163784@qq.com 
Table 1. Energy consumption and import trade in Greece in 2018.

\begin{tabular}{|c|c|c|c|}
\hline & Consumptiont & $\begin{array}{c}\text { Import } \\
\text { trade } \\
\text { volume }\end{array}$ & $\begin{array}{c}\text { Imports } \\
\text { (US } \\
\mathbf{\$ 1 0 , 0 0 0}\end{array}$ \\
\hline Coal & 9.613 million tons & $\begin{array}{c}460,000 \\
\text { tons }\end{array}$ & 4901.65 \\
\hline Crude oil & 16.128 million tons & 2497 tons & 1242626.27 \\
\hline $\begin{array}{c}\text { Natural } \\
\text { gas }\end{array}$ & $\begin{array}{c}4.1 \text { million tons of } \\
\text { oil equivalent }\end{array}$ & $\begin{array}{c}3301443.3 \\
1 \text { tons }\end{array}$ & 126931.40 \\
\hline $\begin{array}{c}\text { Electricit } \\
\mathrm{y}\end{array}$ & $53.8 \mathrm{TWh}$ & $\begin{array}{c}9080143 \\
\mathrm{~kW}\end{array}$ & 49945.89 \\
\hline
\end{tabular}

Data sources: according to Global Data 、 《BP World Energy Statistics Yearbook (2019) collated and calculated.

\subsection{There is an urgent need for the construction of power infrastructure and difficulties in cross- border and cross-island networking.}

One of the key points of power grid construction is the construction of Eurasian power connection network.However, Greece, on the one hand, has not fully emerged from the impact of the European debt crisis, its own economic base is not stable, unable to independently complete large-scale infrastructure investment.On the other hand, Greece does not have an advantage in the field of trans-sea transmission networking.China's power grid and energy enterprises, relying on the core technologies and power grid operation and management advantages in the fields of ultra-high voltage and smart grid, have the foundation to promote bilateral cooperation. They can explore a new mode of integrated cooperation in "investment and construction" and actively participate in the construction and operation management of Greek power infrastructure.

2.3 Targets for renewable energy generation is too high, but the progress in the transformation of low-carbon energy sources is slow.

The European Union's Renewable Energy for All package, The bill sets new targets for low-carbon development in the EU, That is, renewable energy accounted for 32 per cent of primary energy consumption in 2030, energy efficiency increased to 32.5 per cent and carbon emissions decreased by 40 per cent compared with 1990. To achieve the goal, The EU calls on member states to develop a series of measures to encourage energy conservation, improve energy efficiency, develop renewable energy and limit the development of coal and electricity. As requested by the EU, March 2019, Greece has a National Energy and Climate Plan, Energy low-carbon transformation as an important direction of energy development. According to the National Energy and Climate Plan developed by
Greece, By 2030, Renewable energy generation will account for $56.1 \%$ of total power generation. This target already exceeds the EU target of 50 per cent of total electricity generation by 2030 for renewable energy. (Table 2)

Table 2. Energy Generation Objectives of the Greek National Energy and Climate Plan

\begin{tabular}{|c|c|c|c|}
\hline $\begin{array}{c}\text { Energy } \\
\text { generation } \\
\text { targets }\end{array}$ & 2020 & 2025 & 2030 \\
\hline $\begin{array}{c}\text { Biomass power } \\
\text { generation }\end{array}$ & $0.07 \mathrm{GW}$ & $0.12 \mathrm{GW}$ & $\mathrm{GW} 0.32$ \\
\hline Hydropower & $\mathrm{GW} \mathrm{3.42}$ & $3.72 \mathrm{GW}$ & $3.86 \mathrm{GW}$ \\
\hline Wind power & $\mathrm{GW} \mathrm{2.83}$ & $4.04 \mathrm{GW}$ & $6.62 \mathrm{GW}$ \\
\hline $\begin{array}{c}\text { Photovoltaic } \\
\text { power generation }\end{array}$ & $3.54 \mathrm{GW}$ & $\mathrm{GW} \mathrm{5.33}$ & $6.76 \mathrm{GW}$ \\
\hline $\begin{array}{c}\text { photothermal } \\
\text { power generation }\end{array}$ & $0 \mathrm{GW}$ & $0.07 \mathrm{GW}$ & $0.07 \mathrm{GW}$ \\
\hline $\begin{array}{c}\text { Geothermal } \\
\text { power generation }\end{array}$ & $0 \mathrm{GW}$ & $0 \mathrm{GW}$ & $0.08 \mathrm{GW}$ \\
\hline
\end{tabular}

Data sources: Report of the National Energy and Climate Plan of Greece

Greece is rich in renewable energy resources such as solar and wind energy. However, at present, from the point of view of energy structure, in 2018, Greece's renewable energy generation was $15.1 \mathrm{TWh}$, accounting for 27.9 percent of the total power generation, which is much lower than the average level of 32.3 percent of the EU's 28 countries' renewable energy generation. It is a serious challenge for Greece to complete a substantial power transformation within 10 years.

\section{Prospects of China-EU Energy and Power Cooperation}

According to the energy resource endowment of Greece, the main problems facing the energy industry, the energy development strategy and the advantages of China's energy enterprises, the Sino-Greek energy cooperation has broad prospects in the following key areas:

\subsection{The privatization of Greek power assets provides an opportunity for Chinese power enterprises to invest in Greece.}

Greece will continue to privatize state-owned distribution assets, transmission assets and power generation assets in order to ease fiscal pressure and continue to seek IMF and EU assistance. China's electric power enterprises have capital, technology, management advantages, cooperation potential is huge.According to the results of the second debt assessment negotiations between Greece and creditors, advancing energy reform will be the focus of the next reform, mainly to break the monopoly of the state public power company on the electricity market. The Greek privatization fund 
disclosed that the state public power company has been included in the next privatization project.This provides a favorable opportunity for Chinese power enterprises to participate in its privatization process.

\subsection{The advantages of wind power and new energy of Chinese enterprises will contribute to the development and construction of new energy technology cooperation and projects in Greece.}

Greece, as a member of the EU, needs to implement the EU's low-carbon development goals and will achieve the goal of 32 per cent of primary energy consumption by 2030 for renewable energy ,32.5 per cent for energy efficiency and 40 per cent reduction in carbon emissions compared with 1990.Therefore, the development of photovoltaic, wind power and other new energy sources to replace coal and electricity with new energy is the most important measure to achieve the goal of low carbon development in Greece. China's wind power, new energy and other areas have significant advantages, in line with Greece's domestic demand for new energy development.At present, Chinese power enterprises have invested in photovoltaic and wind power projects in Greece, laying a business foundation for further expansion of cooperation.

\section{Conclusions}

\subsection{Enhanced policy coordination and guidance at the national level}

4.1.1 Further strengthen energy policy and energy planning docking.Actively communicate the experience of the two countries in energy transformation, overcome the energy structure of "rich coal, lack of oil and less gas ", and timely introduce energy development plans, key development areas and list of key projects to enterprises in the two countries. Strengthen energy technology and energy standards cooperation and exchange, reduce energy cooperation technical standards barriers. Put energy cooperation in the more important areas of capacity cooperation between the two countries, and cooperate in the introduction of fiscal, financial and customs facilitation measures.

4.1.2 Strengthen communication and coordination with the European Union to properly resolve the investment conflict caused by the third Energy Act of the European Union. The progress of the reform of Chinese stateowned enterprises is introduced to the European Union through the Chinese and Greek governments, which shows that Chinese state-owned enterprises participate in the Greek energy market as independent entities.

4.1.3 Strengthen the synergy between China's energy and power enterprises. Cooperate with China's energy and power enterprises, especially the upstream and downstream enterprises in the power industry, to avoid the internal vicious competition among Chinese power enterprises, and to guide Chinese enterprises to avoid the risks caused by the third Energy Act.

\subsection{Improving investment strategies and capacity-building at the enterprise level.}

4.2.1 Around the Greek energy development focus on the rational distribution of Greek energy market. Consolidating energy security, promoting low-carbon energy transformation and promoting energy infrastructure connectivity are the main directions of energy development in Greece. Enterprises participating in Sino-Greek energy cooperation should focus on Greek energy development and select potential and sustainable development cooperation areas.

4.2.2 From the overall point of view of energy development, comprehensive technical and economic analysis, project selection process. Considering the process of energy transformation, the substitution of clean energy to traditional energy, the downward trend of new energy cost and the price comparison of different energy sources, the technical economy of the project is considered comprehensively.

4.2.3 Around the Greek energy market to strengthen project risk prevention. Focus on the Greek economic recovery process uncertainty, business environment, energy transformation uncertainty, energy costs rise and other risks, prepare ahead of time risk response plan.

4.2.4 Integration into the local economic and social development of Greece, actively fulfill social responsibilities. To respect the role of Greece as an important regional influence country in leading the regional energy transformation and promoting the interconnection of energy infrastructure in South-Eastern Europe, to actively participate in regional energy cooperation, to actively participate in environmental protection, to promote employment, public welfare and other activities, and to create a responsible image of China's energy enterprises.

\section{Acknowledgments :}

This work is supported by the science and technology project of State Grid Beijing Electric Power Co.,Ltd ( Research on the evaluation methods of companies' cross-border mergers and acquisitions projects and overseas expansion of energy Internet business strategies under the new situation ;No.:SGBJDK00KJJS2000132) 


\section{References}

1. Xue Shihua. East Mediterranean Oil Pipeline Project [N].] powered by Energy Triangle Sinopec ,201907-05(005).

2. Sheng Zhang Ming. Development of Sino-Greek Maritime Cooperation and Bilateral Relations [D].] under the "Belt and Road" Framework Shanghai Academy of Social Sciences ,(2019)

3. Shen Qinhan. A study on the orientation of energy policy in Central and Eastern European countries in the context of European integration [D].]; and East China Normal University, (2019)

4. Sturgeon Ulis, Wang Xiaobo. Greece: Committed to the development of an export-oriented economy [J].China Investment (English and Chinese),2019(09):52-57.

5. Ji Junqiang. An Analysis of Sino-Greek Economic and Trade Relations in the Context of "Belt and Road D]. Central China normal University, (2019)

6. Zhou Dan. Greece invested 35 billion euros in energy transformation [J].] Chinese and foreign energy,24 (2019)

7. Yao Teng. Chinese and foreign companies to sign the Greek Thermal Power Plant Project [J].] China Equipment Engineering ,5(2019)

8. Wu Shaoxin. A Study on the Differentiation Strategy of China's Foreign Direct Investment in Southern European Energy Industry [J]. Economic Research Reference ,31(2017)

9. Lefevre T, Pacudan R, Todoc J L. Power in the Philippines: market prospects and investment opportunities[J]. Indian Journal of Biochemistry \& Biophysics, 1997, 51(1):81-86.

10. Chandran $T$. Investment in Power Sector: Past Trend and Short-Term Prospect[J]. Journal of Social and Economic Development, 2003, 5:40-68.

11. T Ziyadov. Prospects of Caspian gas and its potential markets[J]. _titleCentral Asia and the Caucasus, 2004(5(29)).

12. Silva B C, Alex W. Investment, regulation and market: analysis of the risk for the electric power sector $[\mathrm{J}]$.

13. Yuan J, Na C, Yang M . Energy Efficiency and Conservation in China's Power Sector: Progress and Prospects. China's Energy Efficiency and Conservation, 2016.

14. Nezhad H G , Sarkar A, Worzala M . Energy Efficiency Opportunities in the Power Sector in China: Lessons Learned from a DSM Project in Zhejiang and Guangdong Provinces. 1999.

15. Aktymbayeva A, Orazgaliyeva A, Omarova A, et al. The Central Asian Economies of Water-energy security: The Future Role of Hydro and Fuel-based Systems. 2021.

16. Xue Q, Wang Z, Zhang Y . Environmental Benefit and Investment Value of Hydrogen-Based
Wind-Energy Storage System[J]. Frontiers in Energy Research, 2021, 9.

17. Volkova E A, Makarov A A, Makarova A S, et al. The technical-economic and investment policy for the power sector within the framework of the energy strategy of Russia. 1996.

18. Saygin D, Kempener R, Wagner N, et al. The Implications for Renewable Energy Innovation of Doubling the Share of Renewables in the Global Energy Mix between 2010 and 2030[J]. Energies, 2015, 8(6):5828-5865.

19. Subhes, Bhattacharyya. Independent Power Projects in Developing Countries: Legal Investment Protection and Consequence for Development[J]. International Journal of Energy Sector Management, 2010.

20. Spivak M, Spivak M . "Analysis of the electric power sector in China: energy mix, trends and perspectives". 2006.

21. Lui M, Holburn G, Associate Professor, et al. Regulatory Risk and Private Investment in Renewable Energy Technologies: A Study of the Ontario Wind Power Sector. 2009.

22. Konovalova O E . RENEWABLE RIVER RESOURCES OF THE MURMANSK REGION AND THEIR USE IN THE ENERGY SECTOR: YESTERDAY, TODAY, TOMORROW. 2020.

23. Lokupitiya $\mathrm{E}$. Investment potential of energy sector projects in the clean development mechanism[M]. 2002.

24. Pettersson F , Lundmark R. Investment decisions and the implementation of climate policies in the Swedish power sector[J]. Forum for Economics \& the Environment, 2007.

25. Xin-Gang Z, Tian-Tian F, Yu M, et al. Analysis on investment strategies in China: the case of biomass direct combustion power generation sector[J]. Renewable and Sustainable Energy Reviews, 2015, 42:760-772.

26. Steyn, Grove. Governance, finance and investment Decision making and risk in the electric power sector[J]. 2001.

27. Ukowska A . The role of the hydrocarbon transmission system towards achieving the status of energy superpower in the 21 st century[J]. Scientific Journal of Silesian University of Technology. Series Transport, 2021, 110:211-220.

28. Akn-Olum G, Bhringer C, Rutherford T, et al. Economic and environmental impacts of a proposed 'Carbon adder' on New York's energy market[J]. Climate Policy, 2021(2):1-20.

29. Huenteler J T , Hankinson D J , Rosenthal N, et al. Cost Recovery and Financial Viability of the Power Sector in Developing Countries: Insights from 15 Case Studies[J]. Social Science Electronic Publishing. 